\begin{tabular}{c} 
Volume and Issues Obtainable at Center for Sustainability Research and Consultancy \\
Journal of Accounting and Finance in Emerging Economies \\
ISSN: 2519-0318ISSN (E) 2518-8488 \\
Volume 4: Issue 1June 2018 \\
CSRC \\
Journal homepage: www.publishing.globalcsrc.org/jafee \\
\hline
\end{tabular}

\title{
Predicting Bankruptcy Using Z-Score and Z Double Prime (Z"): A Study of Pakistan Stock Exchange
}

\author{
${ }^{1}$ Sadia Irshad, ${ }^{2}$ Maria Shams Khakwani, ${ }^{3}$ Azka Qureshi, ${ }^{4}$ Irum Saba, ${ }^{5}$ Sadia Ishaque \\ ${ }^{1}$ Assistant Professor, Institute of Management Sciences, The Women University, Multan, Pakistan \\ saadirsh@gmail.com \\ ${ }^{2}$ Lecturer, Institute of Management Sciences, The Women University, Multan, Pakistan \\ maria.shams@wum.edu.pk \\ ${ }^{3}$ MS Scholar, Department of Business Administration, Air University Multan Campus, Pakistan \\ azkakoraishy@gmail.com \\ ${ }^{4}$ Assistant Professor, IBA Karachi, Pakistan. isaba@iba.edu.pk \\ ${ }^{5}$ Lecturer, Department of Business Administration, Air University Multan Campus, Pakistan \\ sadia.ishaque@aumc.edu.pk
}

\section{ARTICLEDETAILS \\ History \\ Revised format: May 2018 \\ Available online: June 2018}

\section{Keywords}

Financial Sustainability,

Bankruptcy, Z-Score, Z”,

Financial distress

\section{JEL Classification:}

Q56,G33, G10

\begin{abstract}
Due to the unprecedented happenings and dynamic conditions of international economic system, firms are always at the verge of bankruptcy no matter how sound they are, their sustainability is always in jeopardy. Besides, lenders are continuously raising red flags and giving consistent warnings about possible perils of corporate failure due to fragile economic conditions and increasing debt levels in both corporate and individual businesses these days. Hence there was an exigency to 'develop indicators for monitoring long term progress and sustainability of companies. Thereof it would contribute in illustrating to business analysts, firm stakeholders about the relevance of embracing these active checks for predicting bankruptcy as a sustainable business practice. This created a bizarre cult to look into the matter seriously. For this there is no mantra, no clever feats, sure-fire quick strategies. Instead there are welldefined, simple, systematic and sophisticated models to assess sustainability of companies. Thus, to avoid the tide of massive/substantial corporate failure and any future catastrophe; there is a dire need to identify the most suitable and preeminent model that can truly forecast the likelihood of default ahead of time in given circumstances. And, mainstay of this study is to provide an answer of question in hand by comparing two most venerable model choices i.e. Altman's Z-score and Z double prime (Z").
\end{abstract}

(C) 2018 The authors, under a Creative Commons Attribution-Non Commercial 4.0

Corresponding author's email address: maria.shams@wum.edu.pk

Recommended citation: Irshad, S., Khakwani, M.S., Qureshi, A., Saba, I., Ishaque, S. (2018). Predicting Bankruptcy Using Z-Score and Z Double Prime (Z"): A Study of Pakistan Stock Exchange. Journal of Accounting and Finance in Emerging Economies, 4(1) 47-62

DOI: $10.26710 /$ jafee.v4i1.344

\section{Introduction}

A corporation's main aspiration is to setup a lucrative business for its shareholders. In today's world where business failure is an inescapable phenomenon experienced in both developed and developing countries, the ingenuity of maintaining sustainability is something that must be inquired from today's successful businesses. Since the last decade businesses are failing at an ever-alarming rate. According to figures by US Census Bureau of Labor Statistics in 2015, every year there are only 400,000 
businesses which shows a sustainable portfolio whereas the failures are 470,000 . Thus, it is pretty much obvious that there are not as much of businesses that show a sustainability portfolio than the ones that confront failures around the whole corner. This figure seems just too scary. Pakistan being a developing country is very instable from both political and economic perspectives and thus a deteriorating sustainability profile of businesses is being observed there. This tremendous fall in the sustainability profile of businesses is due to the fierce competition among companies in market place followed by economic downturn. Financial chaos of 2008 has also made a sizeable contribution in throwing the firms out of business. Thus, these corporate scandals and substantial failures during last decennium have initiated an extended and deepened research on developing indicators for assessing the sustainability of businesses. Even companies now are more proactive and likelier to adopt such measures that may help them in ensuring the sustainability of their companies. Thus far, much emphasis has been given to the significance of bankruptcy prediction models for tracking sustainability of companies, hence, to discern and pore over timely signals to the nervous lenders and other stakeholders looking for any sign of financial distress. These models for forecasting financial distress has potential to assess the sustainability profile of companies and their likelihood of bankruptcy in near future.

Assessing the financial stability of a company is always a prime concern for accounting executives, business analysts, prospective investors etc. because there are enormous corollaries for both internal and external customers in case of financial distress of a company. Bankruptcy seems to be a big concern for them as they are very much interested in figuring out the ins and outs of investment and to keep track about the near future and sustainability of the firm they are eyeing to invest. Bankruptcy is not something which immediately happen rather it is followed by a series of events. So, to be bankrupt, a firm must be in financial distress in first place. Financial distress is actually a term of corporate finance and is primarily used to give "early warning" to companies prior to default and, hence, it may be very meaningful for those who wish to protect their stakes in company. Four generic terms stated in literature by Altman and Hotchkiss (2006) to define financial distress are failure, default, insolvency and bankruptcy Failure happens to be when the rate of return realized on capital invested is considerably low than that on the same investments. Failure happens when the rate of return realized on capital invested is considerably low than the rate prevailing on the similar investments. And when average return is not adequate to cover cost of capital, firm is said to be financially distressed. Default is another term akin to financial distress. It exists between debtor and creditor when interest or principal amount is not paid within prescribed time. A more technical term mentioned in this regard is insolvency. It is a situation in which firm is unable to maintain its liquidity and to fulfill its promises, hence, ranked as financially distressed. And the last term associated with distress is bankruptcy which is transpired when the net worth of firm's assets is not more than its total liabilities. It is a set going process borne by a company for its inability to pay the claims.

Thus, bankruptcy prediction has turned out to be an eminent research topic after Beaver (1966) and Altman (1968) have employed financial ratios for predicting bankruptcy. Owing to this, a wide suite of models with their respective strengths and weaknesses (Adnan \& Humayon, 2006) have emerged till date and none of them is superior to other. Therefore, despite of the availability of contemporary options, in this study Grandfather of all i.e. 'Altman's Z-score' and modified Z-score called Z double prime $Z$ " is used. It is also all the way different from the remaining studies because no direct comparison has been cited between these two existing models of Multivariate Discriminant Analysis MDA in case of Pakistan. It is actually the pioneer model of its type i.e. multivariate discriminant analysis. It not only aids/assists in evaluating and measuring financial health of firm but serves as a diagnostic tool too for assessing sustainability prior to distress. The purpose of this research is to test the reliability of ratios provided in Altman Z-score model and to use these ratios in discriminating between financially distressed and healthy companies. It is also aimed to figure out the financial indicator which contributes the most in assessing sustainability, apart from those previously proved. It will help the firms in shifting the focus of their efforts on that very indicator so to minimize the chances of potential default instead of wasting their efforts on least effective indicator.

Precisely, the salient objectives of this research are;

1. To give prominence to the need of assessing the overall sustainability of firm prior to any looming collapse. 
2. To test whether the model has ability to forecast future events with same level of accuracy aforementioned in native study as a statistical evidence (to test whether it overstates or understates the results).

3. To figure out how well the financial stability of a company can be measured vis-a-vis financial ratios used in Z-score and Z" model.

4. And to figure out the financial ratio that has the detrimental effect in leading towards bankruptcy and that can be worked onto minimizing the bankruptcy risk.

Section 2 discusses prior literature relevant to this study. Section 3 describes the research methodology to employ Altman's model. Section 4 provides the data analysis and the final section 5 examines the findings i.e. whether or not Z-score \& Z" model truly predict bankruptcy.

\section{Literature Review}

Studies regarding the use of financial data and accounting numbers to analyze performance dates back to couple of years ago (E.I Altman \& Edith Hotchkiss, 2006). The growing repercussions of business failure on economies worldwide, sparked more deepened, aggressive and dedicated researches in this domain to construct more advanced, sophisticated and powerful statistical models for forecasting bankruptcy and assessing sustainability. The upshot of all this was explosion of wide suite of statistical modelling techniques like Logit Analysis; LA (Ohlson, 1980), Probit Analysis; PA (Zmijewski, 1984), Recursive Partitioning Algorithms; RPA (Quinlan, 1986) and Artificial Neural networks; ANN (Odom and Sharda, 1990) each having its explicit assumptions and specific computational complexities. Some of them are either too confined or some are too outmoded in their forecasting ability but they also have their respective strengths and weaknesses as well (Adnan \& Humayon, 2006). However, this paper doesn't contain an exhaustive list of all subsequent studies made in this field except a few along with modelling techniques that are familiarized till date and are also discussed in the later section.

\subsection{Univariate Analysis}

The first ever classical approach in this ratio analysis was made by Beaver, W. H. (1966). He used almost 30 ratios, categorizes them into a group of 6 and figured out that cash flow to debt ratio is most appropriate (Cuvakhin \& Gertmenian, 2003). However, the shortcoming of his work was rooted in the type of analysis itself i.e. univariate analysis. It only accounts for single ratio at a time, so results may be vague and biased for not incorporating all ratios simultaneously. Furthermore, a single ratio can never truly reflect the overall financial status of firm. Besides this boundary values were assigned for post failure i.e. financial status of firm is misclassified always. Its limitations were realized later and there was a need to introduce a more complicated set of ratios with greater empirical applications, maximum accuracy and improved predictive ability.

\subsection{Multivariate Discriminant Analysis}

Multi discriminant analysis is another approach to calculate bankruptcy. It is a statistical technique very much analogous to regression analysis. By means of its multiple measurements can be aggregated to produce composite score called discriminant score, and, this discriminant score is calculated by means of regression equation called discriminant function that further helps to differentiate between two priori groups. Shortly, the objective of this multivariate technique is to maximally differentiate a sample of firms into dichotomous distinct dimensions. Here this discriminant function turns out as;

$$
\mathrm{Z}=\mathrm{a}+\mathrm{b} 1(\mathrm{X} 1)+\mathrm{b} 2(\mathrm{X} 2)+\ldots .+\mathrm{bn}(\mathrm{Xn})
$$

Here; $\mathrm{Z}$ is discriminant score or $\mathrm{Z}$-score, $\mathrm{a}$ is constant and $\mathrm{b} 1$ and $\mathrm{b} 2$ are discriminant coefficient and implies effect of $\mathrm{x} 1$ and $\mathrm{x} 2$ on chances of firm to become bankrupt, where $\mathrm{x} 1$ and $\mathrm{x} 2$ are independent variables or predictors.

\subsubsection{Z-Score \& Z” model}

Though Beaver's work was a failure but it paved the way for others to follow. Following his footsteps, Altman, E.I. (1968) just did that. He defied the worth of univariate analysis and introduces a more successful and sophisticated model called 'Z-score model' which outperformed the former one. He exploited 22 different financial ratios to 66 firms and categorizes them into a list of 5 variables or 
ratios i.e. profitability, solvency, liquidity, sales activity and financial leverage but he did this via multivariate discriminant analysis (MDA).

This approach was used first ever by eponymous Altman, E.I., (1968) and the model thus evolved gives the best yield of its times in classifying the firms into priori groups, distressed and nondistressed, and it can correctly forecast the company's sustainability with up to $90 \%$ accuracy prior to one year of default, with $86 \%$ accuracy prior to two years and this percentage drops out sharply with longer horizons (1968).

Despite of gaining so much popularity, the Z-score model devised previously, only holds for publicly listed companies and industrial firms (manufacturing and construction) (Taffler, 1983) not for the nonlisted companies and manufacturing firms (Chuvakhin \& Gertmenian, 2003). So, after realizing the defects inherent in his model, Altman make adjustments in his original model to accommodate above mentioned companies as well and came up with a more refined model called Z" model (Altman, 1995). The revised model only accounts for the first four ratios i.e. the ratio of Sales/Total (X5) was dropped out and the weights to rest of the four ratios were objectively reassigned. Due to this update, only its predictive ability increased to $94 \%$ prior to a year of default as compared to $90 \%$ in original Zscore.

\subsection{Conditional Probability Models}

In early 1980's, MDA technique was substituted by other techniques like Logit analysis (LA) (Ohlson, 1980), Probit analysis (PA) (Zmijewski, 1984) etc. Hillegeist, S. A. (2004) underlines that, two econometric impediments were there in Ohlson logit model. Sample selection bias for incorporating one non-random observation for every single bankrupt company is first one. And second is the inability to account for the time variations and associated bankruptcy risk that it reflects. Probit Analysis (Zmijewski, 1984) was not proficient in assessing failure in small private enterprises. So, both of these were not much promising approaches and were not adopted much.

\subsection{Recursive partitioning algorithm (RPA)}

Recursive partitioning algorithm (RPA) is another statistical technique in which non-parametric sampling is used. Nevertheless, due to two limitation of RPA one being a forward selection method whereas other is partitioning process continuation, its use in predicting bankruptcy is minimum [14].

\subsection{Artificial Neural Network (ANN)}

The most popular approach among intelligent techniques is probably neural networks (Demyanyk \& Hasan, 2010). It by means of an algorithm which imitates the biological neural networks of human nervous system That is, it is a network of interconnected neurons just like in human nervous system and they are called artificial neurons. In contrast to statistical techniques, this technique has two unique advantages. The very first is, being non-parametric it has no underlying assumptions unlike in statistical techniques. Other is that, it relies on non-linear approaches consequently its possibilities for testing complex data patterns are widespread. However, the downside of model that render it nonuseful is that it is very responsive towards cyclical or temporal economic changes, this makes their interpretation very difficult (Paliwal \& Kumar, 2009).

\subsection{Revisiting Z-Score}

Among many studies on the application of models, one is conducted by Ijaz, M. S., Hunjra, A. I., Hameed, Z., \& Maqbool, A. [16] to ascertain the likelihood of failure in listed companies of Pakistan who were a part of sugar industry. They made a comparison between Altman's Z-score model and current ratio, taking a sample of 35 firms from sugar industry and data was taken for a time frame of 2009 to 2010 and it was explored that Z-score is reliable method for predicting bankruptcy.

Pok, W. C. [17] performed an analysis of Malaysian Syariah-compliant stocks to inspect about financial stability of the sample of 477 companies. And his results recommend that only $35.43 \%$ of the firms were financially stable using Altman's Z-score whereas the results acquired through Z" were much better i.e. $59.75 \%$ of firms were found to be financially healthy using the later 2011-12 model. This qualifies Z" as more reliable tool than former one.

In one more study Altman's model was applied to assess the financial status of firms in Indian logistics Industry from 2005-06 and by Tyagi, V. [18], and he founds that firms in logistics industry 
are doing satisfactory.

Kumar, M. [19] assess the financial performance of King Fisher airlines using Altman's Z-score model and its findings indicate that firm was continuously facing looming losses from 2005 to 2012, and if no protective strategies are soon adapted, it will end up in default.

In successive years, Kumar, M. N., \& Rao, V. S. H. [20] executed a research in which they estimated credit risk and bankruptcy prediction under Basel II. The findings suggest that Z" can predict up to 98.6\% accurately whereas the comparative accuracy of Z-score was 93.5\%. It makes Z" a far better predictor than Z-score.

Another study in this realm is by Ncube, T. [21] to assess the corporate failure using data of all listed firms in stock exchange of Zimbawe from 2011-13 to aware government and general public about the need of detecting sick firms in time and it results so declared showed that $83.33 \%$ of the firms were prone to distress whereas the rest were safe.

A similar research was performed by Thai, S. B., Goh, H. H., HengTeh, B., Wong, J., \& San Ong, T. [22] in Malaysia using multivariate discriminant analysis model undertaking a sample of 30 firms listed in Bursa Malaysia, 15 in each priori group and its results indicate that Altman's Z-score model has a prediction accuracy of $76.7 \%$ and ratio of working capital to total assets is the best financial indicator of all.

Besides this Malik, M. S., Awais, M., Timsal, A., \& Hayat, F. [23] also analyzed the empirical applications of Altman model in textile sector of Pakistan to account for the performance of firms in this industry before and after crises and figured out that most of the firms failed to sustain the crises and collapse.

In another research carried by Anjum, S. [2] all the studies on significance of Altman's Z-score model were discussed and results show that it can be safely exercised to modern economy.

An advanced research made in similar context was of Jan, A., \& Marimuthu, M. [24]. Its mainstay was to revisit Altman's model for assessing the sustainability profile of Islamic Banking Industry. The procured results thus again proves that; Altman's model is a viable option for assessing sustainability and predicting bankruptcy.

A relevant work found in this regard is of Mihalovič, M. [25], who decided to compare the predictive performance of the two models i.e. a logistic regression model and MDA model. The sample encompasses a total of 236 firms Slovakia, dissociated into two priori groups. He also endeavors to catch on the best financial predictor for assessing sustainability. The results comprehended that logistic regression model is better than the later whereas Working Capital to Total Assets WC/TA \& Retained Earnings to Total Assets (RE/TA) are better predictors. Parallel to above mentioned researches, Mohammed, S. [26] too contributed in the available discourse by monitoring the sustainability of a firm Result Cement Company SAOG and its subsidiaries in Oman. The tool adopted for analysis was Altman's Z- score. And the findings revealed that company and its subsidiaries were financially stable and tool proved as a reliable one.

Though subsequent researchers had explored countless distinct models and have done worth adding researches in this realm, yet to choose the most appropriate and suitable model out of this wide suit is never a Hobson's choice. Still there is a dearth of discourse on such model choices and financial indicator that best captures the risk of bankruptcy. So, from the myriad of options, there was a dire need to ascertain the most suitable and preeminent model that can truly forecast the likelihood of default ahead of time in given circumstances. Along with that, it was also seriously felt to identify a financial indicator that plays the most dominant part in pushing the firm towards disturbing its stability. So that firms start to work on it and maintain its sustainability in order to reduce their chances of default. So, this research is not only restricted towards mere identification of the best model 
rather this research aims to serve manifold as it first helps the firms to realize the problem i.e. bankruptcy, than identify a measure to work on and finally provide them a reliable and well tested tool to help diagnose the problem before time. And for all this a list of hypotheses is developed and is given below.

\title{
3. Hypothesis
}

Following hypothesis are formulated for the empirical verification of this research:

H1: Z" model is the best, most accurate and reliable method to identify bankruptcy risk

H2: Financial ratios truly capture the risk of bankruptcy.

H3: Working Capital to Total Assets (WC/TA) is the best financial indicator.

H4: Retained Earnings to Total Assets (RE/TA) is the best financial indicator.

H5: Earnings before Interest and Tax to Total Assets (EBIT/TA) is the best financial indicator.

H6: Market Value of equity to Total Liabilities (MV/TL) is the best financial indicator.

H7: Sales to Total Assets (S/TA) is the best financial indicator.

\section{Materials and Methods}

This section covers a comprehensive detail of research methodology applicable in this study.

\subsection{Sampling}

The sample of firms gathered for this analysis encompasses a list of 60 firms, 30 in each priori group as their corresponding match. The firms are selected on the basis of industry and asset size. The companies contained within the sample are from diverse industries of Pakistan except financial ones because the chances of sustainability of such firms rely highly on economic conditions of a country which are very much uncertain especially in Pakistan.

The following list entails the name of industries from which the sample is derived;

\section{Table 1. List of Industries}

\author{
Textile \\ Industrial Metals and Mining \\ Construction and Materials (Cement) \\ Electronics and Electrical Goods \\ Engineering \\ Automobile and Parts \\ Food and Beverages \\ Paper, paperboard and products \\ Household Goods \\ Fuel \& Energy
}

\subsection{Selection of Distressed Firms}

The distressed firms that are considered for analysis are those that have lodged a bankruptcy petition in court or failed to satisfy the provisions of clause 5.11.1. (e) of Pakistan stock exchange (PSX) Regulations and are removed from the daily diaries of PSX and their operations are also winded up by Securities and Exchange Commission of Pakistan (SECP) in a period stretching from 2000 to 2015.

\subsection{Selection of Non-Distressed Firms}

Healthy companies are picked out on the following criteria;

(1) The company which is publicly listed on the stock exchange of Pakistan at least five years before 2015

(2) The company has at least five years of fully disclosed financial information.

\subsection{Source of Data Collection}

The genealogy of this research is quantitative in nature. So, in this study we have worked with secondary data, obtained from balance sheet analysis (BSA) of firms published by State Bank of Pakistan (SBP) till the date they become bankrupt. For example, if a firm listed in year 2008 in Pakistan Stock Exchange (PSX) and went bankrupt in year 2014 then data for its financial analysis will be included from year 2009 to 2013 i.e. as per the above stated rule. 


\subsection{Altman Z-Score Model}

$\mathrm{Z}$-Score $=1.2 \mathrm{X} 1+1.4 \mathrm{X} 2+3.3 \mathrm{X} 3+0.6 \mathrm{X} 4+1.0 \mathrm{X} 5$

Where;

$\mathrm{X} 1$ is Working capital/total assets

$\mathrm{X} 2$ is Retained earnings/total assets

X3 is Earnings before Interest \& Tax (EBIT)/total assets

$\mathrm{X} 4$ is Market value of equity/total liabilities

$\mathrm{X} 5$ is Sales/total assets (measured in number of times, not percentages)

And,

$\mathrm{Z}$ is overall index score.

The lower is the Z-score, the higher are the odds that company will go bankrupt. Altman also provided cut-off scores for generalizability of results. A company having score of 3 or above is ranked as healthy, and a score below 1.8 means that it has highest odds of becoming bankrupt Altman, E. I. (1968).

\subsection{Altman Z-Double Prime (Z") Model}

$Z "=6.56 \mathrm{X} 1+3.26 \mathrm{X} 2+6.72 \mathrm{X} 3+1.05 \mathrm{X} 4$

Where;

$\mathrm{X} 1=$ Working Capital /Total Assets

$\mathrm{X} 2=$ Retained earnings /Total Assets

X3 = Earnings before Interest and Tax / Total Assets

$\mathrm{X} 4=$ Market Value of Equity / Total Liabilities

Z" is overall index score.

The cut off scores for generalizability of results in this model are that a firm having score of 2.6 or above is ranked as healthy, whereas firm with a score below 1.1 is considered to have highest odds of becoming bankrupt Altman, E. I. (2000), Zopounidis, C., \& Paraschou, D. (1998).

\begin{tabular}{ccc}
\hline \multicolumn{3}{c}{ Table 2. Cut off scores } \\
\hline Z-Score & Z" \\
Healthy & $\geq 3$ & $\geq 2.6$ \\
Bankrupt & $<1.8$ & $<1.1$ \\
\hline
\end{tabular}

\subsection{Measurement of variables}

Financial ratio analysis let us develop a more comprehensive understanding of firm's position and device a strategy that can be well applied to cater the firm's financial problems Altman, E. I. (1968). It generally facilitates in discriminating a bankrupt firm from matched control sample i.e. healthy firms under observation. In this research, five ratios indicating financial distress are brought to use by Altman for making appropriate decisions in his model which serve as independent variables and are given below; whereas the dependent variables are Z-score \& Z” prime.

\subsubsection{Working Capital / Total Assets (X1=WC/TA)}

Working capital is the difference between current assets and current liabilities. It is considered as liquid asset for company to meet their short-term obligation effectively. A company is able to meet its short-term obligation when there is positive working capital. When there is insufficient working capital, the company is concerned that they will not be able to pay their short-term debt. Normally, the companies that are facing financial difficulties will have a shrinking asset which will cause them to be non-liquid and fail to pay their creditors.

\subsubsection{Earnings before Interest and Tax / Total Assets (X2=RE/TA)}

This ratio is used to evaluate the company's ability to generate operating profit with existing asset. When the company has high profit with low asset, it has a relatively low chance of getting default. It is due to the dollar of asset that is able to generate a larger amount of operating profit. On the other way, lower income might not be enough to cover company's daily expenses.

4.7.3. Retained Earnings / Total Assets (X3=EBIT/TA) 
Retained earnings are the amount of earning that is not paid out as dividend. The purpose of retaining the company's earning is to allow the company to reinvest without adopting external fund with more cost. In other words, retained earnings can be used to measure the extent of a company by using leverage. If this ratio is high, it means that there is sufficient funding for the firm to reinvest. If the ratio is low, the company will borrow instead of retaining earnings to finance their investment. This will increase the company's chance of being default.

\subsubsection{Market Value of Equity / Total Liabilities (X4=MV/TL)}

By referring to this ratio, we are able to measure how fast the company's asset would decline when the company become insolvent - when liability exceed asset of the company. This ratio is not considered based on pure fundamental because it computes with the company's market value. Market capitalization indicates the level of confidence the company gives to the market. A higher-level ratio indicates that the company has a higher chance to sustain when there is an economic downturn.

\subsubsection{Sales / Total Assets (X5=S/TA)}

This ratio is also known as asset turnover. It indicates how effective the company uses a single dollar of asset to generate sales. Sales are the amount earned without considering cost, interest and tax. When this ratio is high, it indicates that with the amount of assets, the company is able to expand their market share. If the company with low asset turnover is not using proper strategy to improve their sales, they may not have a promising future.

\section{Test Procedures}

Table 3 is used to test significance of variables i.e. whether they truly capture the risk of bankruptcy and it also measures the potential of each predictor variable. And if level of significance of $F$ values is $\leq 0.05$, then it indicates that the variable surely contributes to model and also discriminates between the two groups. Here all the independent variables are highly significant with values less than 0.05 and they also have high standardized coefficients attached to them, which shows that better discriminating power between two groups. Wilks' lambda also serves the same purpose i.e. it too measures the variable's potential in predicting bankruptcy. It has a value of 1 and the lower the value of Wilks' Lambda the better a variable can discriminate between groups. Here MV/TL shows the best discriminating ability with Wilks' Lambda equals to .638 i.e. lowest of all and also has the highest standardized coefficient and significance in case of Z" whereas in case of Z-Score S/TA and MV/TL have significantly smaller values as compared to others. In short, it is pretty much obvious from the above results that greater significance, high standardized coefficient and smaller Wilks' lambda of all variables shows their best contribution in making up the model.

\begin{tabular}{lllllll}
\hline \multicolumn{7}{c}{ Table 3 Test of Equality of Group Means } \\
\hline Z” & Wilks' Lambda & F & df1 & df2 & Sig. \\
& WC/TA & .899 & 4.819 & 1 & 45 & .034 \\
& RE/TA & .903 & 4.617 & 1 & 45 & .037 \\
& EBIT/TA & .898 & 4.900 & 1 & 45 & .032 \\
Z & .638 & 24.423 & 1 & 45 & .000 \\
& MV/TL & .722 & 17.319 & 1 & 45 & .000 \\
& WC/TA & .810 & 10.562 & 1 & 45 & .002 \\
& RE/TA & .925 & 1.630 & 1 & 45 & .053 \\
& EBIT/TA & .713 & 18.123 & 1 & 45 & .000 \\
& MV/TL & .372 & 75.835 & 1 & 45 & .000 \\
\hline
\end{tabular}

Table 4(b) reports standardized canonical discriminant function coefficients for both models in which each predictor variable has been assigned with an index which are same as standardized beta coefficients in regression analysis i.e. it reflects the unique contribution of independent variables like WC/TA, RE/TA in defining bankruptcy. Here, the strongest indicator in defining bankruptcy in case of $Z$ " is MV/TL with value of 0.797 whereas in Z-Score S/TA and MV/TL contributes most respectively. 
Table 4 Standardized Canonical Discriminant Function Coefficients for Z score

\begin{tabular}{lll} 
& & Function \\
Z" & 1 & \\
& WC/TA & .343 \\
RE/TA & .095 \\
EBIT/TA & .338 \\
MV/TL & .797 \\
Z-Score & WC/TA & .214 \\
& RE/TA & .209 \\
EBIT/TA & .023 \\
MV/TL & .324 \\
S/TA & .796 \\
\hline
\end{tabular}

\subsection{Classification Accuracy of Altman's Models}

The classification table 5.1.1. shows that in case of Z", 24 of 24 previously defaulted companies from the cases included in creating model are accurately classified, 15 out of 21 healthy companies are accurately classified i.e. $100 \%$ of defaulted and $71.4 \%$ of healthy firms are correctly classified. Overall prediction power of Z" is $86.7 \%$. When re-estimated for ZScore, it was found that 20 of 22 previous defaulted companies from the cases included in creating model are accurately classified, 18 out of 25 healthy companies are accurately classified i.e. $90.9 \%$ of defaulted and $72.0 \%$ of healthy firms are correctly classified. Thus, overall prediction power of Z-Score is $80.6 \%$. 
Table 5 Classification Results

\begin{tabular}{|c|c|c|c|c|c|c|}
\hline & & & Z" Risk & Predicted & Tembership & Total \\
\hline & & & & Default & healthy & \\
\hline Z' & Accuracy & $\%$ & Default & 100 & .0 & 24 \\
\hline & & $N$ & & 24 & 0 & 100.0 \\
\hline & Accuracy & $\%$ & Healthy & 28.6 & 71.4 & 100.0 \\
\hline & & $N$ & & 6 & 15 & 21 \\
\hline Z-Score & Accuracy & $\%$ & Default & 90.9 & 9.1 & 100.0 \\
\hline & & $N$ & & 20 & 2 & 22 \\
\hline & Accuracy & $\%$ & Healthy & 28.0 & 72.0 & 100.0 \\
\hline & & $N$ & & 7 & 18 & 25 \\
\hline
\end{tabular}

a. Accuracy rates represents the correct classification using Altman's Model Coefficients

b. $87.6 \%$ of selected cases correctly classified using Altman's Z"'

c. $80.6 \%$ of selected cases correctly classified using Altman's Z-Score

\section{Results \& Discussion}

By using our sample of 30 distressed and 30 non-distressed firms, classification accuracy of both models of Altman is evaluated through multivariate discriminant analysis. Results suggest that $\mathrm{Z}$ double prime (Z") procures a good classification result of $86.7 \%$ as compared to original estimate of $94 \%$ and Z-Score marked with an accuracy of $80.6 \%$ instead of $90 \%$ in the original holdout sample. Furthermore, it seems that contribution of financial ratios in predicting financial distress may also vary overtime. For example, statistics shows that in Z double prime (Z") model market value of equity to total liabilities whereas in Zscore market value of equity to total liabilities and sales to total assets receives the highest coefficient score, making it obvious that these two variables are most significant and have the strongest ability in predicting bankruptcy. Market value of equity to total liabilities is the most appropriate variable for firms to work on in order to avoid the chances of default in general whereas in particular, market value of equity to total liabilities and sales to total assets are found to have a significant contribution in forecasting and leading a firm towards bankruptcy. In summary, this study offers some useful insights about the benefits of exercising bankruptcy prediction models in general, and testing the classification accuracy, significance and predictive ability of financial ratios in particular. And these reflections can later on prove beneficial for investors, managers, government and financial policy makers in designing frameworks, laws and policies to minimize the occurrence of any distress in near times, to develop protective measures to mitigate its effects if any and to provide substantial support to the distressed companies.

\begin{tabular}{cc}
\hline \multicolumn{2}{c}{ Table 6 } \\
\hline Hypothesis & Results \\
H1 & Accepted \\
H2 & Accepted \\
H3 & Rejected \\
H4 & Rejected \\
H5 & Rejected \\
H6 & Accepted \\
H7 & Accepted \\
\hline
\end{tabular}

\section{Conclusion}

The presentlabove forth study is an attempt to objectively quantify, compare and analyze Pakistani firms that are either vulnerable to default or have already declared bankruptcy using proportionate sample (i.e. 30 in each group) and most relevant data of recent times i.e. from 2000 to 2015, by means of two most venerable model choices i.e. Altman's Z-score and Z", falling under the category of statistical techniques and employing multivariate discriminant analysis to serve for the purpose. In both models, we make a fair use of conventional accounting indicators and financial ratios owing to their classification ability and 
popularity in literature in terms of bankruptcy prediction. Yet, based on the cut off score the two models differ in terms of their classification accuracy and predictive power. Z" model correctly classifies the firms in underlying sample with a maximum accuracy of up to $86.7 \%$ prior to one year of default as compared to the original hold out sample of Altman i.e. 94\% which is exceptionally good whereas Atman's Z -Score was only $80.6 \%$ accurate as compared to $90 \%$ in original sample which is indeed acceptable. Thus, classification results of Z" model demonstrates its improved accuracy over existing model of Z-score for failure prediction. These results are a reinforcement of the results proposed by Pok, W. C. and Kumar, M. N., \& Rao, V. S. H. So, we can say that results declare Z" as the most accurate and reliable assessment tool out of the two.

This study is not merely limited towards identification of most accurate and reliable model rather this research aims to serve manifold as it also calculates a financial indicator that is highly capable, strongly interpret and contribute the most in defining the firm's overall sustainability profile, hence, suggesting the firms an obvious solution to work on and to manage their risks. And that very financial indicator is Market Value of equity to total liabilities. As, the firm that is more volatile in its equity or has a low market value of equity is more likely to default than a firm that is quite stable in this ratio or has a high market value of equity to total liabilities. Other variables like working capital to total assets, retained earnings to total assets, earnings before interest and tax to total assets and sales to total assets also captures the risk of bankruptcy but comparatively to a lesser extent (Rashid, A., \& Abbas, Q.,2011, Abid et al, 2012).

By use of most relevant and recent data, the results of this study serve as an early warning for firms in the underlying sample about their financial status. It may help the firms to assess sustainability and detect their likelihood of default if any thus to take necessary actions to avoid colossal losses in future. Besides this, it may also serve as an indicator for all respective shareholders and analysts about the risky profile of firm who aims to include it in their portfolio.

In summary, this study offers some useful insights about the benefits of exercising bankruptcy prediction models in general, and testing the classification accuracy, significance and predictive ability of financial ratios in particular. And these reflections can later on assist/prove beneficial for investors, managers, government and financial policy makers in designing frameworks, laws and policies to minimize the occurrence of any distress in near times, to develop protective measures to mitigate its effects if any and to provide substantial support to the distressed companies.

\section{Future Research Recommendations}

In this study we have not only quantified risk of bankruptcy in firms but also compared important and distinct facts about the performance of the two conventional but venerable models in question and thus it is empirically evident from the findings that Z double prime (Z") has superior performance than Z-score in evaluation of impending success or failure of firm. So, this makes the model a highly recommended tool by researcher to ascertain bankruptcy risk among companies in future. However, the model is not the only most relevant and accurate assessment tool in this regard. Researchers and practitioners recommend to subject all modelling techniques on underling data for thorough empirical testing simultaneously, the information so condensed will be used to judge the true position of companies. Another major recommendation that can be made to Altman's failure prediction model after this study is to reflect changing economic, market and industry conditions in its input for improving the status. Perhaps, this can be done by adding up variety of explanatory variables that may serve as better predictors by re-estimating the coefficients of model and expanding no of firms in underlying sample. But as mentioned earlier that one obvious impediment of this research is absence of sufficient data for companies which has confined the study to just a few variables and small sample size. Furthermore, other models can also be widely applied and tested at the same time for reflecting better picture of firms in question. To a final note, this research can also be exercised for financial and non-listed sector of Pakistan to retrieve more remote trends in this domain.

\section{References}


Abid, .A. S., Kouser, R, Aamir M., \& Hussain M., (2012) The Impact of the Corporate Governance and the Ownership Structure on the Firm's Financial Performance and Its Risk Taking Behaviour International research journal of finance and economics(IRJFE) Issue (93), pp. 44-55

Adnan Aziz, M., \& Dar, H. A. (2006). Predicting corporate bankruptcy: where we stand? Corporate Governance: The international journal of business in society, 6(1), 18-33.

Altman, E. I. (1968). Financial ratios, discriminant analysis and the prediction of corporate bankruptcy. The journal of finance, 23(4), 589-609.

Altman, E. I. (2000). Predicting financial distress of companies: revisiting the Z-score and ZETA models. Stern School of Business, New York University, 9-12.

Altman, E.I., \& Hotchkiss, E. (Eds.). (2006). corporate financial distress and bankruptcy: predict and avoid bankruptcy, analyze and invest in distressed debt ( $3^{\text {rd }}$ ed.). Hoboken, NJ: Wiley

Anjum, S. (2012). Business bankruptcy prediction models: A significant study of the Altman's Z-score model. Asian Journal of Management Research, 3(1), 212-219.

Beaver, W. H. (1966). Financial ratios as predictors of failure. Journal of accounting research, 71-111.

Chuvakhin, N., \& Gertmenian, L. W. (2003). Predicting bankruptcy in the WorldCom age. Journal of Contemporary Business Practice, 6(1), 3-8.

Demyanyk, Y., \& Hasan, I. (2010). Financial crises and bank failures: A review of prediction methods. Omega, 38(5), 315-324.

Hillegeist, S. A., Keating, E. K., Cram, D. P., \& Lundstedt, K. G. (2004). Assessing the probability of bankruptcy. Review of accounting studies, 9(1), 5-34.

Ijaz, M. S., Hunjra, A. I., Hameed, Z., \& Maqbool, A. (2013). Assessing the financial failure using Z-score and current ratio: A case of sugar sector listed companies of Karachi stock exchange.

Jan, A., \& Marimuthu, M. (2015). Bankruptcy and sustainability: A conceptual review on Islamic banking industry. Global Business and Management Research, 7(1), 109.

Kumar, M. N., \& Rao, V. S. H. (2015). A new methodology for estimating internal credit risk and bankruptcy prediction under Basel II Regime. Computational Economics, 46(1), 83-102.

Kumar, M., \& Anand, M. (2013). Assessing Financial Health of a Firm Using Altman's Original and Revised Z-Score Models: A Case of Kingfisher Airlines Ltd (India). Journal of Applied Management and Investments, 2(1), 36-48.

Malik, M. S., Awais, M., Timsal, A., \& Hayat, F. Z-Score Model: Analysis and Implication on Textile Sector of Pakistan.

Mihalovic, M. (2016). Performance comparison of multiple discriminant analysis and logit models in bankruptcy prediction. Economics \& Sociology, 9(4), 101.

Mohammed, S. (2016). Bankruptcy Prediction Using the Altman Z-score Model in Oman: A Case Study of Raysut Cement Company SAOG and its subsidiaries. Australasian Accounting Business \& Finance Journal, 10(4), 70.

Ncube, T. PREDICTING CORPORATE FAILURE.

Odom, M. D., \& Sharda, R. (1990, June). A neural network model for bankruptcy prediction. In Neural Networks, 1990, 1990 IJCNN International Joint Conference on (pp. 163-168). IEEE.

Ohlson, J. A. (1980). Financial ratios and the probabilistic prediction of bankruptcy. Journal of accounting research, 109-131.

Paliwal, M., \& Kumar, U. A. (2009). Neural networks and statistical techniques: A review of applications. Expert systems with applications, 36(1), 2-17.

Pok, W. C. (2012). Analysis of Syariah quantitative screening norms among Malaysia Syariah-compliant stocks. Investment Management and Financial Innovations, 9(2), 69-80.

Quinlan, J. R. (1986). Induction of decision trees. Machine learning, 1(1), 81-106.

Rashid, A., \& Abbas, Q. (2011). Predicting Bankruptcy in Pakistan. Theoretical \& Applied Economics, 18(9).

Taffler, R. J. (1983). The assessment of company solvency and performance using a statistical model. Accounting and Business Research, 13(52), 295-308.

Thai, S. B., Goh, H. H., HengTeh, B., Wong, J., \& San Ong, T. (2014). A Revisited of Altman Z-Score Model for Companies Listed in Bursa Malaysia. International Journal of Business and Social Science, 5(12). 
Tyagi, V. (2014). A Study to measures the financial health of selected firms with special reference to Indian logistic industry: an application of Altman's Z score. Industrial Engineering Letters, 4(4), 43-54.

Zmijewski, M. E. (1984). Methodological issues related to the estimation of financial distress prediction models. Journal of Accounting research, 59-82.

Zopounidis, C., \& Paraschou, D. (1998). Multicriteria Decision Aid methods for the prediction of business failure (Vol. 12). Springer Science \& Business Media.

\section{Appendix 1}

Comparison of Altman Z-Score (1968) and Z"-Double Prime (1995) Bankruptcy Prediction Models

\begin{tabular}{|c|c|c|c|}
\hline 1 & & Altman's 1968 Paper & Altman's 1995 Paper \\
\hline 2 & Title & $\begin{array}{c}\text { Edward I. Altman } \\
\text { New York University }\end{array}$ & Altman \& Hartzell and Peck \\
\hline 3 & Year & 1968, September & 1995 \\
\hline 4 & Dependent Variable & Bankrupt/Non-Bankrupt firms & EM Scores \\
\hline 5 & $\begin{array}{l}\text { Independent } \\
\text { Variables }\end{array}$ & Five out of 22 & Four out of 22 \\
\hline 6 & Sample Size & 66 paired (33 each) & More than 750 US firms \\
\hline 7 & Industry & Manufacturing & $\begin{array}{l}\text { Manufacturing and Non- } \\
\text { Manufacturing }\end{array}$ \\
\hline 8 & Data Source & $\begin{array}{c}\text { Income Statement and Balance } \\
\text { Sheet }\end{array}$ & $\begin{array}{c}\text { Income Statement and Balance } \\
\text { Sheet }\end{array}$ \\
\hline 9 & $\begin{array}{c}\text { Financial Ratios } \\
\text { used as Independent } \\
\text { Variables }\end{array}$ & $\begin{array}{c}\text { WC/TA, RE/TA, EBIT/TA, } \\
\text { MV/TL, S/TA }\end{array}$ & $\begin{array}{l}\text { WC/TA,RE/TA,EBIT/TA, } \\
\text { MV/TL }\end{array}$ \\
\hline 10 & $\begin{array}{l}\text { Classification } \\
\text { Accuracy }\end{array}$ & $90 \%$ & $94 \%$ \\
\hline 11 & $\begin{array}{l}\text { Order of Relative } \\
\text { Contribution }\end{array}$ & $\begin{array}{c}\text { EBIT/TA, RE/TA,W/TA,S/TA, } \\
\text { MV/TL }\end{array}$ & $\begin{array}{c}\text { EBIT/TA,WC/TA,RE/TA,MV/ } \\
\text { TL }\end{array}$ \\
\hline 12 & $\begin{array}{c}\text { Needed items of } \\
\text { Financial Statement }\end{array}$ & $\begin{array}{l}\text { CA, CL, TA, TL, RE, EBIT, } \\
\text { Sales, No of shares }\end{array}$ & $\begin{array}{l}\text { CA, CL, TA, TL, RE, EBIT, } \\
\text { No of shares }\end{array}$ \\
\hline 13 & Application & $\begin{array}{l}\text { Publicly held manufacturing } \\
\text { firms }\end{array}$ & $\begin{array}{l}\text { Manufacturing and non- } \\
\text { manufacturing firms with rated } \\
\text { bonds outstanding }\end{array}$ \\
\hline
\end{tabular}

\section{Appendix 2: List of companies taken as testing sample}

\begin{tabular}{|l|l|}
\hline Ayesha Textile Mills Limited & Hajra Textile Mills Limited \\
\hline Asim Textile Mills Limited & Ideal Spinning Mills Limited \\
\hline Ashfaq Textile Mills Limited. & Idrees Textile Mills Limited \\
\hline Artistic Denim Mills Ltd. & Ishtiaq Textile Mills Limited \\
\hline Ansari Sugar Mills Ltd & Mitchells Fruit Farms Limited \\
\hline Annoor Textile Mills Limited & Mehr Dastgir Textile Mills Limited \\
\hline Atlas Honda Ltd. & Medi Glass Limited \\
\hline Atlas Engineering Ltd & National Foods Limited \\
\hline Akzo Nobel Pakistan Ltd & Nestle Pakistan Limited \\
\hline Bela Automotives Ltd. & Olympia Textile Mills Limited \\
\hline Bhanero Textile Mills Limited & Pak Leather Crafts Limited \\
\hline Bawany Air Product Limited & Pakistan Gum and Chemiclas Limited \\
\hline Biafo Industries Limited & Pakistan Paper Prouducts Limited \\
\hline Chakwal Spinning Mills Limited & Quality Textile Mills Ltd \\
\hline
\end{tabular}




\begin{tabular}{|l|l|}
\hline Crescent Textile Mills Limited & Resham Textile Industries Ltd \\
\hline Clover Pakistan Limited & Shifa International Hospitals Limited \\
\hline (Colony) Thal Textile Mills Limited & S. G. Fibres Ltd \\
\hline (Colony) Sarhad Textile Mills Limited & S. S. Oil Mills Ltd \\
\hline Colgate Palmolive (Pakistan) Limited & Shezan International Ltd \\
\hline Cherat Cement Company Limited & Sind Fine Textile Mills Ltd \\
\hline Cherat Packaging Limited. & Saleem Denim Industries Limited \\
\hline Dewan Khalid Textile Mills Limited & Sazgar Engineering Works Limited \\
\hline Dewan Textile Mills Limited & Sitara Chemical Industries Limited \\
\hline Din Textile Mills Limited & Sitara Peroxide Limited \\
\hline Dewan Automotive Engineering Limited & Transmission Engineering Industries Limited \\
\hline Dost Steels Limited & Wah Noble Chemicals Limited \\
\hline Dadabhoy Construction Technology Limited & Morafco Industries Limited \\
\hline Dadabhoy Cement Industries Limited & Murree Brewery Company Limited \\
\hline Data Textile Limited & Data Agro Limited \\
\hline Descon Oxychem Limited & HinoPak Motors Limited \\
\hline Dewan Cement Limited & Asim Textile Mills Limited \\
\hline Engro Corporation Limited & Diamond Industries Limited \\
\hline Engro Polymer and Chemicals Limited & Baluchistan Wheels Limited \\
\hline Fatima Enterprizes Limited & Globe (OE) Textile Mills Limited \\
\hline Faisal Spinning Mills Limited & Gulistan Spinning Mills Limited \\
\hline Fazal Cloth Mills Limited & Gadoon Textile Mills Ltd \\
\hline Fateh Textile Mills Limited & Goodluck Industries Limited \\
\hline Gulistan Textile Mills Ltd & Ghani Value Glass Limited \\
\hline Gul Ahmed Textile Mills Limited & Honda Atlas Cars (Pakistan) Limited \\
\hline Globe Textile Mills Limited & Husein Industries Limited \\
\hline & \\
\hline
\end{tabular}

\section{Appendix 3: Financially distressed companies indicated by Z"}

\begin{tabular}{|l|l|}
\hline Ansari Sugar Mills Ltd & Sind Fine Textile Mills Ltd \\
\hline Annoor Textile Mills Limited & S. S. Oil Mills Ltd \\
\hline Ashfaq Textile Mills Limited & Saleem Denim Industries Limited \\
\hline Dewan Textile Mills Limited & S. G. Fibres Ltd \\
\hline Bela Automotives Ltd. & Morafco Industries Limited \\
\hline Dewan Khalid Textile Mills Limited & Din Textile Mills Limited \\
\hline Globe Textile Mills Limited & (Colony) Sarhad Textile Mills Limited \\
\hline Gulistan Textile Mills Limited & (Colony) Thal Textile Mills Limited \\
\hline Husein Industries Limited & Gadoon Textile Mills Limited \\
\hline Gulshan Spinning Mills Limited & Dadabhoy Cement Industries Limited \\
\hline Globe (OE) Textile Mills Limited & Dost Steels Limited \\
\hline Dewan Automotive Engineering Limited & Data Textile Limited \\
\hline Idrees Textile Mills Limited & Fateh Textile Mills Limited \\
\hline Kohat Textile Mills Limited & Fatima Enterprizes Limited \\
\hline Olympia Textile Mills Limited & Khurshid Spinning Mills Limited \\
\hline Transmission Engineering Industries Limited & Ishtiaq Textile Mills Limited \\
\hline Dadabhoy Construction Technology Limited & Pak Leather Crafts Limited \\
\hline
\end{tabular}

\section{Appendix 4: Financially distressed companies indicated by Z-Score}




\begin{tabular}{|l|l|}
\hline Dost Steels Limited & Fatima Enterprizes Limited \\
\hline Ashfaq Textile Mills Limited & Data Textile Limited \\
\hline Dadabhoy Construction Technology Limited & Khurshid Spinning Mills Limited \\
\hline Husein Industries Limited & Annoor Textile Mills Limited \\
\hline (Colony) Thal Textile Mills Limited & Husein Industries Limited \\
\hline Globe (OE) Textile Mills Limited & Fateh Textile Mills Limited \\
\hline Saleem Denim Industries Limited & Morafco Industries Limited \\
\hline Dadabhoy Cement Industries Limited & Globe Textile Mills Limited \\
\hline Husein Industries Limited & Saleem Denim Industries Limited \\
\hline Bela Automotive Limited & S. G. Fibres Ltd \\
\hline Dadabhoy Construction Technology Limited & (Colony) Sarhad Textile Mills Limited \\
\hline Ansari Sugar Mills Ltd & Asim Textile Mills Limited \\
\hline Transmission Engineering Industries Limited & Olympia Textile Mills Limited \\
\hline Dewan Automotive Engineering Limited & Gulistan Textile Mills Limited \\
\hline
\end{tabular}


